\title{
MATHEMATICS LEARNING BY USING LEARNING MODEL TAPPS TO IMPROVE STUDENTS' MATHEMATICAL COMMUNICATION SKILL
}

\author{
Ely Syafitri ${ }^{1}$, Eva Margaretha Saragih ${ }^{2}$, Dewi Astuti ${ }^{3}$ \\ Pendidikan Matematika Universitas Asahan, Jl. Jendral Ahmad Yani Kisaran \\ ely.syafitri1@gmail.com,margarethaevasaragih@gmail.com,dwi.damilt@gmail.com
}

\begin{abstract}
This research aims to find out the influence of learning model Cooperative of TAPPS type to the students' mathematical communication skill. Communication is a very important part of mathematics and mathematics education. Communication is a way to share ideas and clarify understanding. Through communication ideas can be mirrored, refined, discussed, and developed. TAPPS model become a popular way to help students to think about solving a problem. One student person becomes problem solver and one other becomes a listener. Each of members has their own task to follow the rules. This research was conducted in SMA Negeri I Kisaran. This research was conducted by using experimental quasi method, involved 82 students as the sample. The results revealed that the TAPPS learning model affected the students' mathematical communication skill. It was seen from the average score of students' mathematical communication skill tested by TAPPS learning model was 70.9 and the mean score of students' mathematical communication skill tested by conventional method was 64.1 with $t_{\text {-hitung }}=14.36$ and $t_{- \text {table }}=1.99$. The conclusion of this research was mathematics learning on mathematical logic material using TAPPS learning model had an effect on students' mathematical communication skill.
\end{abstract}

Keywords: Mathematical Communication, Skill, Mathematical Logic, Thinking Aloud Pair Problem Solver (TAPPS) and Education.

\section{INTRODUCTION}

Education which able to support the future development, it is the education enable to develop the potential of learners, so that people can face and solve the problem of life ahead. Mathematics is a universal science underlying the development of modern technology, has an important role in various disciplines and develop the human mind power. Rapid development in the field of technology, information and communication nowadays based on the development of mathematics in the field of number theory, algebra, analysis, probability theory, and discrete mathematics. In fact mathematics is regarded as a difficult and confusing subject. Most mathematics teachers only emphasize mere mastery of material and more one-way communication with students, so that students are less active in conveying ideas. In addition, many mathematics teachers prefer the results obtained without seeing the process of the students. This makes students lazy to communicate ideas, ideas and thoughts, they just want to get the right answers without knowing the exact mathematical problems. Less attractive or monotonous tools and media also affect the attractiveness of students in learning. In essence, communication skills and problem solving are important in mathematics learning because students are required to think and then communicate to other students so that they understand each other. During the communication occurs students are required to be able to interpret the language of mathematics into everyday language that is easy to understand so that the purpose of learning mathematics is achieved. Communication is a very important part of mathematics and mathematics education. Communication is a way to share ideas and clarify understanding. Through communication ideas can be mirrored, refined, discussed, and developed.

Mathematical communication has an important role in the learning of mathematics, because through mathematical communication students can express, explain, describe, hearing that take students on a deep understanding of mathematics. To measure mathematical abilities required indicator-indicator. Indicators mathematical communication abilities in mathematics according to NCTM (2000) [2] the ability of the students are: (1) organize and consolidate mathematical thinking 
(mathematical thinking) them through communication; (2) communicate their mathematical thinking coherently (arranged logically) and clear to his friends, teachers and others; (3) analyze and evaluate the mathematical thinking (mathematical thinking) and the strategies used by another person; (4) use the language of mathematics to express mathematical ideas correctly.

Meanwhile, according to Sumarmo (2003), communication skills include the ability of the student (a) connecting the real objects, drawings, and diagrams into the idea of mathematics; (b) explain ideas, situations and relationships mathematical orally or in writing with real objects, pictures, graphs and algebra; (c) declare a daily occurrence in the language or math symbol; (d) listening, discuss, and write about mathematics; (e) read with comprehension or writing mathematical presentation; (f) make a conjecture, make arguments, formulating definitions and generalizations; (g) explaining and making inquiries about the math they have learned.[4]

Learning mathematics is often linked to using one's problem solving skill. While strong conceptual understanding is important in learning mathematics, it is also essential for the students to learn how to use their knowledge effectively in solving mathematics problems. Different problem solving strategies have been described in literatures but some suggest that students tend not to use strategies with too many stages (Jeon et al. 2005). In this study, we mainly used a well-known example of problem solving strategy proposed by Polya (1945), which consists of the following four stages: (i) understanding the problem, (ii) devising a plan, (iii) carrying out the plan, and (iv) looking back over the process.

Thinking aloud pair problem solving, which was first developed by Arthur Whimbey, aims to better understand thinking among the students (Whimbey \& Lochhead, 1999) and to develop students' cognitive processes associated with problem solving (Kotsopoulus, 2010). Thinking aloud pair problem solving is mainly based on thinking aloud and listening (Jeon et al., 2005). As the name suggests, this involves students working in pairs. One student (the problem solver) is required to read the problem aloud and think aloud during the problem solving process, which includes verbalizing everything they are thinking and doing. Another student (the listener) attends to the problem solver's thinking and reminds him/ her to keep saying aloud what he or she is thinking or doing, while also asking for clarifications and pointing out errors being made. It is important to highlight that listeners are not allowed to attempt to solve the problems or give correct answers. Instead of merely imitating worked examples, this instructional method focuses on helping the students learn by being aware of their thinking process in tackling mathematics problems. Students are not always able to express their mathematical understanding in detail. Often, answers from the students were given in the form of one word or sometimes, keywords. Thinking aloud during problem solving may reveal much more about the students' personally constructed understanding compared to assessing them from their written works (Watson, 2002). However this may also be restricted to how well the students are able to express their thinking process verbally.

Application of method or learning approach that viewed according to characteristics of students will avoid boredom and create a comfortable and fun atmosphere in learning process. Teacher can use some learning approach to achieve learning goals and improving student learning outcome. TAPPS model become a popular way to help students to think about solving a problem. This model can also monitor students so they recognize what they understand and what they do not understand. In this model the teacher can also teach the students to solve problems, how to solve problems in pairs, and also how to think hard and voice his thoughts in solving a problem. In the TAPPS model, the class students are divided into teams, each team consists of two people. One student person becomes problem solver and one other become a listener. Each of members has their own task to follow the rules.

The first thing to do by problem solver is to read the question followed by revealing all the things to solve the problem on the matter. A listener must make problem solver keep talking. The main task of a listener is to understand every step or error made problem solver. A good listener not only knows the steps taken by problem solver but also understand the reasons used problem solver to choose the step. The listener is recommended to indicate when an error has occurred but does not mention the location of the error and the listener is trying not to solve the problem solver. After a problem is solved, the two students exchange tasks. So that all students have the opportunity to become problem solver and listener.

Based on the problem above, the researcher is interested to conduct research on the teaching of mathematics using cooperative learning model of Thinking Aloud Pair Problem Solving (TAPPS). Learning model Cooperative Type of Thinking Aloud Pair Problem Solving (TAPPS) is a learning model involving two students working together to solve a problem. 


\section{PURPOSE OF STUDY}

To find out the influence of learning model Cooperative of TAPPS type to the students' mathematical communication skill. Communication is a very important part of mathematics and mathematics education.

\section{COMMUNICATION MATHEMATICALLY}

Mathematics is generally identical to the calculation of figures and formulas, giving rise to the notion that communication skills cannot be built on learning mathematics. Communication skills are very important in the learning of mathematics. According to The Intended Learning Outcomes (Sumarno. 2013) [11], mathematical communication is an essential skill in mathematics that is the ability to express mathematical ideas coherently to friends, teachers and others through the spoken and written language. Through this mathematical communication skills students can develop an understanding of mathematics when using correct mathematical language to write about mathematics, clarify ideas and learn to make the argument and represents the mathematical ideas verbally, images and symbols.

This assumption is of course not correct, because according to the Greenes and Schulman, mathematical communication has a role: (1) a central force for students in formulating mathematical concepts and strategies; (2) capital for student success and completion of the approach in the exploration and investigation of mathematics; (3) a place for students to communicate with his friends to obtain information, share their thoughts and discoveries, brainstorming, assess and sharpen ideas to convince others.

The ability to communicate becomes one of the conditions that plays an important role as it helps in the process of preparing the mind, connecting ideas with other ideas that can fill up the things lacking in the whole network of student ideas. Correspondingly, Lindquist (in Fitrie, 2002: 16). [6] states that we need communication in math if you want to fully achieve social goals, such as mathematics literacy, lifelong learning, and mathematics for everyone.

While building a mathematical communication according to the National Council of Teachers of Mathematics (NCTM, 1989) .[1] provides benefits to students in the form of: (1) Modeling the situation by verbal, written, images, graphics, and algebra; (2) Reflecting and clarified in thinking about mathematical ideas in various situations; (3) Develop an understanding of mathematical ideas, including the role of definitions in mathematics (4) Using the skills of reading, listening, and writing to interpret and evaluate mathematical ideas; (5) The assessment of mathematical ideas through conjecture and convincing reasons; (6) Understanding the value of notation and the role of mathematics in the development of mathematical ideas.

Activities teachers to develop students 'mathematical communication skills, among others: (1) Listen attentively and see the students' ideas; (2) Investigate questions and tasks administered, interesting, and challenging students to think; Ask students to respond and assess their ideas orally and in writing; (3) Assess the depth of understanding or idea expressed in the students' discussion; (4) Decide when and how to present mathematical notation in the language of mathematics in students; (5) Monitor student participation in discussions, deciding when and how to motivate each student to participate.

While indicators of students' skills in mathematical communication in the learning of mathematics by NCTM (2003) .[3] are: (1) communicate their mathematical thinking coherently (arranged logically) and clear to his friends, teachers and others; (2) use the language of mathematics to express mathematical ideas correctly; (3) organize and consolidate mathematical thinking (mathematical thinking) them through communication; (4) analyze and evaluate the mathematical thinking (mathematical thinking) and the strategies used by another person Meanwhile, according to Sumarmo (2013) students' mathematical communication capabilities include: (1) connecting the real objects, drawings, and diagrams into the idea of mathematics; (2) explain ideas, situations and relationships mathematical orally or in writing with real objects, pictures, graphs and algebra; (3) declare a daily occurrence in the language or math symbol; (4) listen, discuss, and write about mathematics; (5) read with comprehension or writing mathematical presentation; (6) make a conjecture, make arguments, formulating definitions and generalizations; (7) describes and made inquiries about the math they have learned.

In general, mathematics within the scope of communication includes skills / ability to write, read, discussing and assessing, and discourse (discourse). Without communication in mathematics we 
would have a bit of information, data, and facts about the students in the process of understanding and application of mathematics. Sadiq (2004). [9] "Mathematics is a very powerful communication tool, precise and unambiguous". For example, the notation $40 \times 4$ can be used to express a variety of things, such as:

- Mileage motorcycle for 4 hours at a speed of $40 \mathrm{~km} / \mathrm{h}$.

- The surface area of the pool with a length of 40 meters and a width of 4 meters

- Many of the wheels on the car 40

The above examples have shown that the notation 40 x 4 can express a different matter.

\section{MODEL THINKING ALOUD PAIR PROBLEM SOLVING (TAPPS)}

Whimbey and Lochhead (1999) mentioned that thinking aloud during problem solving aims to ensure that students "do not skip steps in their reasoning, nor miss facts in drawing conclusions" (p. 23). This procedure may also help in identifying different kinds of students' weaknesses, errors and strategies in problem solving (Montague et al., 2011). It is able to provide more information inaccessible through examining students' written work for example, through students' explanations.

Jeon et al. (2005) observed in their investigation on the effectiveness of TAPPS in improving problem solving performance of high school chemistry students that students in both the individual and TAPPS groups performed better in problem solving compared to the control group. They found that students in the individual and TAPPS groups performed better in recalling the related law and mathematics execution. The students in TAPPS group also performed better than the others on conceptual knowledge. Jeon and colleagues (2005) also stated that the verbal interactions between the solvers and listeners could help the students be "more cognizant of both their own thinking and the thinking of other students" (p. 1564). However, they discovered that listeners seemed to gain more benefits from TAPPS than the problem solvers. They found that listeners' 'pointing out' behaviour showed the greatest correlation with their own problem solving performance; listeners' 'agreeing' behaviour to the solvers' statements was also positively correlated to the listeners' problem solving performance. They also discovered that there was a negative correlation between the listeners' 'pointing out' and the solvers' problem solving performance.

In addition, Kotsopoulus (2010) highlighted in her study on examining instances of talking aloud during peer collaborations in mathematics that it is important to teach the students both on how to express their thinking and their learning needs and how to attend to each other's thinking and learning needs in such settings. She mentioned TAPPS as a possible suggestion to achieve this. Ericsson and Simon (1980) argued that thinking out loud does not affect the cognitive processes or performance speed, but instead, it does help students to identify and monitor their own thinking process.

\section{METHODOLOGY}

The population in this study is all students of grade X SMA Negeri I Kisaran in the second semester. There are five classes of students which are X-A to X-E totally about 201 students. This research takes two classes from five classes as the sample. Selection of experimental class and control class, each one class that is X-A class which amount 40 students as experiment class and X-B class which amount 42 students as control class. To measure the early skill of the control class and experimental class is done by pre-test. This type of research is a experimental quasi research, so it takes two research classes consisting of one experimental class and one control class. The chart is illustrated as follows:

\begin{tabular}{|l|c|c|c|}
\hline \multicolumn{1}{|c|}{ Group } & Pre-test & Treatment & Post-test \\
\hline Experiment & $\mathrm{T}_{1}$ & $\mathrm{X}_{1}$ & $\mathrm{~T}_{2}$ \\
Control & $\mathrm{T}_{1}$ & $\mathrm{X}_{2}$ & $\mathrm{~T}_{2}$ \\
\hline
\end{tabular}

Tabel 1. Treatment for Experiment and Control Group 
The variables of this research are the communication ability with the mathematics learning model of the students and the control variable is the potential of the teacher, the material given, the length of the student learning and the student's early skill. To obtain actual data and description of this research topic, the researcher uses data collection tool which is a mathematics test with mathematical logic material. The selected test form is a description.

\section{RESULT AND DISCUSSION}

The research sample consisted of two groups, namely the experimental group (class X-A) which amount 40 students and the control group (class X-B) which amount 42 students. For the experimental group was given the learning treatment by applying cooperative learning model Thinking Type Aloud Pair Problem Solver (TAPPS), while for the control group was given the treatment of learning by applying the lecture method (conventional).

Before doing the teaching and learning process, both classes are pre tested for the purpose of knowing the students' early skill. From the result of the pre test, the result of the students' learning result for the highest grade experiment class 78 and the lowest score 49 with the mean $(x \overline{)}=64.4$ and standard deviation $(\mathrm{SD})=7.71$. While in the control class obtained the highest value of 75 and the lowest value 47 with the average $(x \overline{)}=63.05$ and standard deviation $(\mathrm{SD})=7.75$. Data value average and standard deviation in the pre test data can be seen in the following table:

\begin{tabular}{|c|c|c|c|c|}
\hline \multirow{2}{*}{ Group } & \multicolumn{4}{|c|}{ The Result of Earlier Students } \\
\cline { 2 - 5 } & $\overline{\boldsymbol{x}}$ & SD & Min & Max \\
\hline Experiment & 64.4 & 7.71 & 49 & 78 \\
Control & 63.05 & 7.74 & 47 & 75 \\
\hline
\end{tabular}

Tabel 2. Average of Students' and Group Experiment Earlier Controlling of Pre-test Data

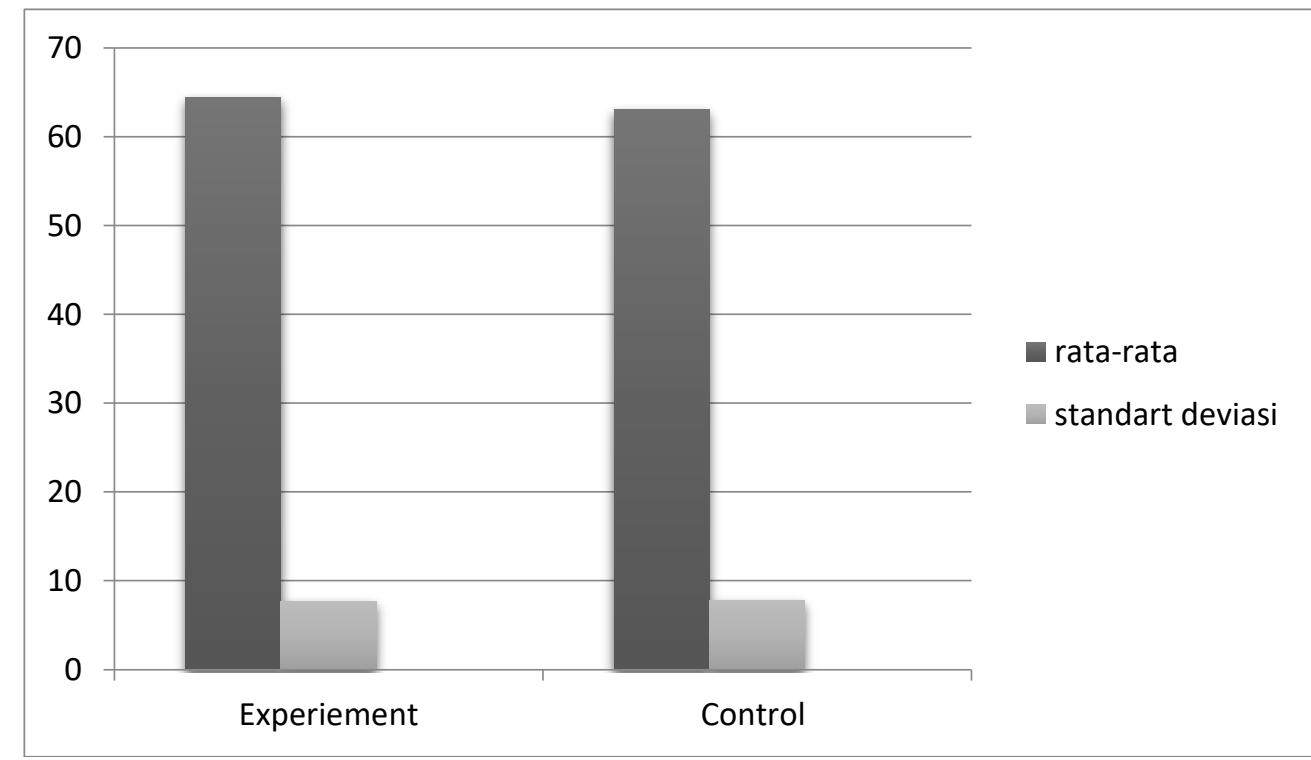

Gambar 1. Average of Students' and Group Experiment Earlier Controlling of

Pre-test Data

The data normality test was performed to find out whether the sample used in this study came from a normally distributed population. Technique used to test data normality by using Liliefors test. 
acceptance or rejection of $\mathrm{H} 0$ based on comparison of Lhitung with Ltabel at significant level $\alpha=0,05$. Normality test is done on data obtained from experiment class. The results of data testing can be seen in the following table:

\begin{tabular}{|c|l|c|c|c|c|}
\hline No. & \multicolumn{1}{|c|}{ Group } & $\mathbf{n}$ & $\mathbf{L}_{\text {hitung }}$ & $\mathbf{L}_{\text {tabel }}$ & Conclusion \\
\hline 1. & Experiment & 40 & 0.1000 & 0.1401 & Normal \\
2. & Control & 42 & 0.0922 & 0.1367 & Normal \\
\hline
\end{tabular}

Tabel 3. Pre-Test Normality Data

From the result of normality test of learning result data above shows that $\mathrm{L}_{\text {hitung }}$ learning in experiment class and control class is below specified denial limit. Thus it can be concluded that the distribution of student learning outcomes in the experimental class and control class is normal distribution

For homogeneity test was used the largest variance test compared to the smallest variance, for pre test obtained $\mathrm{F}_{\text {hitung }}=1.06$ and $\mathrm{F}_{\text {table }}=1.69$ because $\mathrm{F}_{\text {hitung }}<\mathrm{F}_{\text {tabel }}$ it can be concluded that both groups have homogeneous variance.

From the post-test result, the students' learning achievement for the highest grade of experiment was 84 and the lowest score was 55 with the mean $(x \overline{)}=70.8$ and the standard deviation $(\mathrm{SD})=8.12$ While in the control class obtained the highest value of 78 and the lowest value 49 with average average $(x \overline{)}=63.98$ and standard deviation $(\mathrm{SD})=8.04$. For the experimental group test data obtained $\mathrm{L}_{\text {hitung }}=0.1224$ and $\mathrm{L}_{\text {tabel }}=0.1401$ with significant level $\alpha=0.05$, because $\mathrm{L}_{\text {hitung }}<\mathrm{L}_{\text {tabel }}$ it can be concluded that for post test data also normal distribution. For control group data obtained $\mathrm{L}_{\text {hitung }}=$ 0.0989 and $\mathrm{L}_{\text {tabel }}=0.1367$ with significant level $\alpha=0.05$, because $\mathrm{L}_{\text {hitung }}<\mathrm{L}_{\text {tabel }}$ it can be concluded that post test data is normally distributed. For the post test obtained Fcount $=1.11$ and $\mathrm{F}_{\text {table }}=1.69$ because $\mathrm{F}_{\text {hitung }}<\mathrm{F}_{\text {table }}$ it can be concluded that both groups have a homogeneous variance.

\section{CONCLUSION}

The students' mathematical communication skills taught by learning model cooperative TAPPS type have average persentage $21.32 \%$. The best level of indicators of mathematical communication skill is an indicator evaluating mathematical ideas with a percentage of $23.42 \%$, indicator express mathematical ideas percentage value $21.43 \%$ and indicators using mathematical terms $19.10 \%$ of percentage value. The ability of students' mathematical communication taught by learning model of Cooperative TAPPS type is different compared to the mathematical communication ability taught by conventional method seen from hypothesis testing $\mathrm{T}_{\text {hitung }}=14.36$ and $\mathrm{T}_{\text {tabel }}=1.99$ with significant level $\alpha=0.05$, so $\mathrm{T}_{\text {hitung }}=14.36>\mathrm{T}_{\text {tabel }}=1.99$ thus the students' mathematical communication skill taught by learning model Cooperative TAPPS type is higher than the students' mathematical communication skill taught by conventional methods. So it can be concluded that there is influence of learning model Cooperative TAPPS Type toward mathematical communication skill on mathematics logic material. 


\section{REFERENCES}

Arikunto, Suharsimi. 2009. Dasar-Dasar Evaluasi Pendidikan. Jakarta: Bumi Aksara.

Ericsson, K. A., \& Simon, H. 1980. Verbal Reports As Data. Psychological Review, 87, 215-250.

Fachrurazi. 2011. Penerapan Pembelajaran Berbasis Masalah Untuk Meningkatkan Kemampuan Berpikir Kritis Dan Komunikasi Matematis Siswa Sekolah Dasar. Forum Penelitian. Edisi Khusus No.1: 76-89.

Fitrie. 2002. Learning Strategies, Jakarta: The Open University.

Jeon, K., Huffman, D., \& Noh, T. 2005. The Effects Of Thinking Aloud Pair Problem Solving Of High School Students' Chemistry Problem-Solving Performance And Verbal Interactions. Journal Of Chemical Education, 82(10), 1558-1564.

Jihad, Asep. 2008. Evaluasi Pembelajaran. Yogyakarta.

Kotsopoulos, D. 2010. An Analysis Of Talking Aloud During Peer Collaborations In Mathematics. International Journal Of Science And Mathematics Education, 8, 1049-1070.

Margono, S.2013.Metodologi Penelitian Pendidikan. Jakarta: Rineka Cipta.

Montague, M., Krawec, J., \& Rosenzweig, C. 2011. Metacognitive Strategy Use Of Eight-Grade Students With And Without Learning Disabilities During Mathematical Problem Solving: A Think-Aloud Analysis. Journal Of Learning Disabilities, 44(6), 508-520.

National Council Of Teachers Of Mathematics. 1989. Principle And Standards For School Mathematics. Reston, Va: Nctm.

National Council Of Teachers Of Mathematics. 2000. Principle And Standards For School Mathematics. Reston, Va: Nctm.

National Council Of Teachers Of Mathematics. 2003. Principle And Standards For School Mathematics. Reston, Va: Nctm.

Polya, G. 1945. How To Solve It? Garden City, Ny: Doubleday.

Sanjaya, Wina. 2010. Strategi Pembelajaran Berorientasi Standar Proses Pendidikan. Jakarta: Prenada Media.

Shadiq. 2004. Pemecahan Masalah, Penalaran, Dan Komunikasi. Yogyakarta: Makalah Penataran Guru Pppg.

Siregar. 2010. Teori Belajar Dan Pembelajaran. Bogor: Ghalia Indonesia.

Sudjana. 2005. Metoda Statistika. Bandung: Pt. Tarsito Bandung.

Sudjana, Nana. 2010. Penilaian Hasil Proses Belajar Mengajar. Bandung: Pt Remaja Rosdakarya.

Sugiyono. 2010. Metode Penelitian Pendidikan Pendekatan Kuantitatif, Kualitatif Dan Rnd. Bandung: Alfabeta.

Sumarno. Utari, Abdul Qohar. 2013. Improving Mathematical Communication Ability And Self Regulation Learning Of Yunior High Students By Using Reciprocal Teaching. (Indoms. J.M.E Vol. 4 No. 1 January 2013) (Download Tanggal 2 Desember 2016)

Trianto. 2009. Mendesain Model Pembelajaran Inovatif-Progresif. Surabaya: Kencana.

Utari, Sumarmo. 2003. Thinking And Mathematical Disposition: What, Why, And How Developed On Primary And Secondary School Students. Bandung: Itb.

Watson, A. 2002. What Does It Mean To Understand Something And How Do We Know When It Has Happened? In L. Haggarty (Ed.), Teaching Mathematics In Secondary Schools (Pp. 161-175). London: Routledge Falmer.

Whimbey, A., \& Lochhead, J. 1999. Problem Solving And Comprehension.Mahwah, Nj: Lawrence Erlbaum Associates. 